\title{
A new species of Elaphoglossum sect. Lepidoglossa subsect. Muscosa (Dryopteridacae) with cristate spores
}

\author{
Elena Ballenthien, Jan-Hendrik Dudenhöffer, and Michael Kessler
}

Albrecht-von-Haller-Institut für Pflanzenwissenschaften, Abteilung Systematische Botanik, Untere Karspüle 2, D-37073, Göttingen, Germany; e-mail: mkessle2@uni-goettingen.de

\begin{abstract}
A new species from the Bolivian highlands is described as Elaphoglossum cristatum. It is very similar to $E$. engelii but is characterized by a (for subsect. Muscosa unique) cristate perispore structure with irregular deposits (versus papillate spores), more densely ciliate petiole scales (50-80 versus $10-30$ cilia per scale), somewhat thicker blade texture, denser scale cover, and paler, more reddish rhizome scales.
\end{abstract}

Key Words: Bolivia, Dryopteridaceae, Elaphoglossaceae, Muscosa, perispores.

Elaphoglossum Schott ex J. Sm. (Dryopteridaceae) is one of the largest fern genera with about 600 described species (Mickel \& Atehortúa, 1980; Kramer, 1990). Morphologically, the genus is characterized by its usually scaly rhizomes, simple fronds with nearly glabrous to densely scaly blades, usually free veins, acrostichoid sori, and sterile-fertile frond dimorphism. A division of the genus in sections and subsections was proposed by Mickel and Atehortúa (1980) based on morphological traits and is largely supported by molecular studies (Rouhan et al., 2004; Skog et al., 2004).

One of the largest subgroups within Elaphoglossum is section Lepidoglossa H. Christ, characterized primarily by its scaly blades with lanceolate, reniform, round-peltate or stellate scales. Within section Lepidoglossa, the subsection Muscosa Mickel \& Atehortúa, with ca. 15 species, is well-defined by the ovatelanceolate, coriaceous, usually apically obtuse, densely scaly blades, and erose blade scales (Mickel \& Atehortúa, 1980). Furthermore, all seven species studied have large, papillate, frequently collapsed spores that have been proposed as a synapomorphy of the subsection (Moran et al., 2007). In Bolivia, this subsection is represented by three species, E. atrorubens Mickel, E. blandum Rosenst., and E. engelii (H. Karst.) H. Christ (M. Kessler, unpubl. data). The latter species is by far the most common and variable both morphologically and ecologically, growing as epiphytic, saxicolous, or terrestrial plants in humid forests, on rock faces, along roadsides, in grasslands, and among rocks at $1800-3750 \mathrm{~m}$. During a herbarium study of E. engelii, we found two collections that are subtly different morphologically, but that have distinct spores that differ strikingly from all other species of subsection Muscosa and that are here proposed to represent an as yet undescribed species.

Elaphoglossum cristatum E. Ballenthien, J.-H. Dudenhöffer \& M. Kessler, sp. nov. Type: Bolivia, Dept. Cochabamba, Prov. José Carrasco Torrico, $63 \mathrm{~km}$ antigua carretera Cochabamba-Villa Tunari, $17^{\circ}$ 15'S, 6543'W, 3700 m, 2 Jul 1996, Kessler et al. 6875 (holotype: GOET; isotypes: LPB, NY, UC).

(Figs. 1, 2a)

$\mathrm{Ab}$ Elaphoglosso engelii sporis cristatis, squamis petiolorum cum ciliis marginalibus crebrioribus, 50-80 (non 10-30), textura laminarum parce crassiore, indumento squamarum in laminis densiore, squamis rhizomatis pallidioribus rufescentibusque differt.

Rhizomes short-creeping, prostate, apically slightly ascending, 4-8 $\mathrm{mm}$ in diam., densely scaly; scales linear-lanceolate, $5-7 \times 0.2-$ $0.8 \mathrm{~mm}$, dentate to ciliate, light to dark red- 

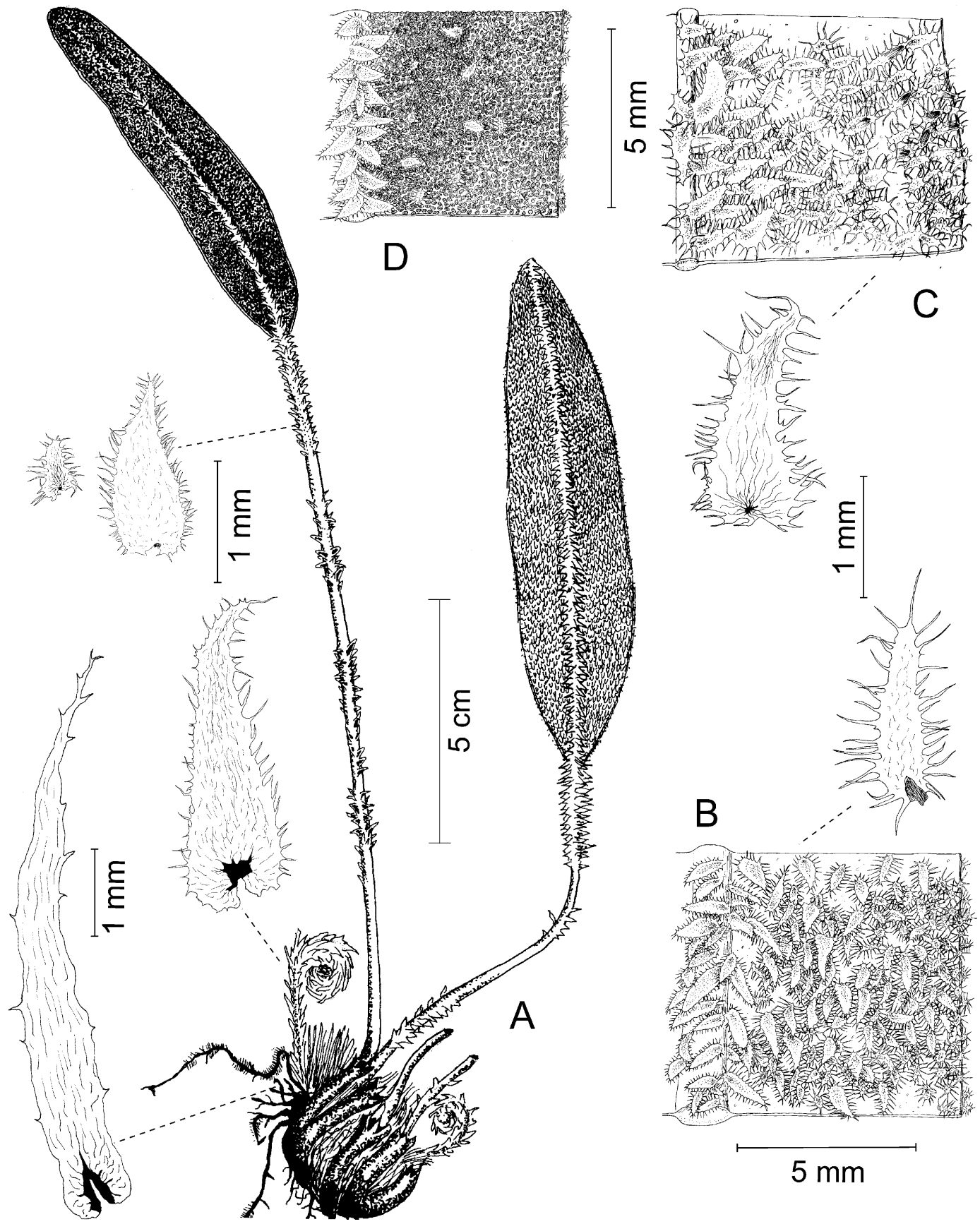

Fig. 1. Elaphoglossum cristatum. A. Habit. B. Adaxial detail of sterile blade. C. Abaxial detail of sterile blade. D. Abaxial detail of fertile blade. (From Kessler et al. 6875, GOET.)

brown, darkening proximally; aerophores absent; phyllopodia absent; sterile fronds 10-40 $\mathrm{cm}$ long, petioles $1 / 3-3 / 4$ frond length, $1-$ $3 \mathrm{~mm}$ in diam., densely scaly; scales of two types, the larger ones ovate-lanceolate, $2-5 \times$ $0.8-1.5 \mathrm{~mm}$, with 50-80 marginal cilia, orangebrown, often with dark cells proximally or medially, the small ones ovate, $0.3-0.1 \times 0.15-$ 

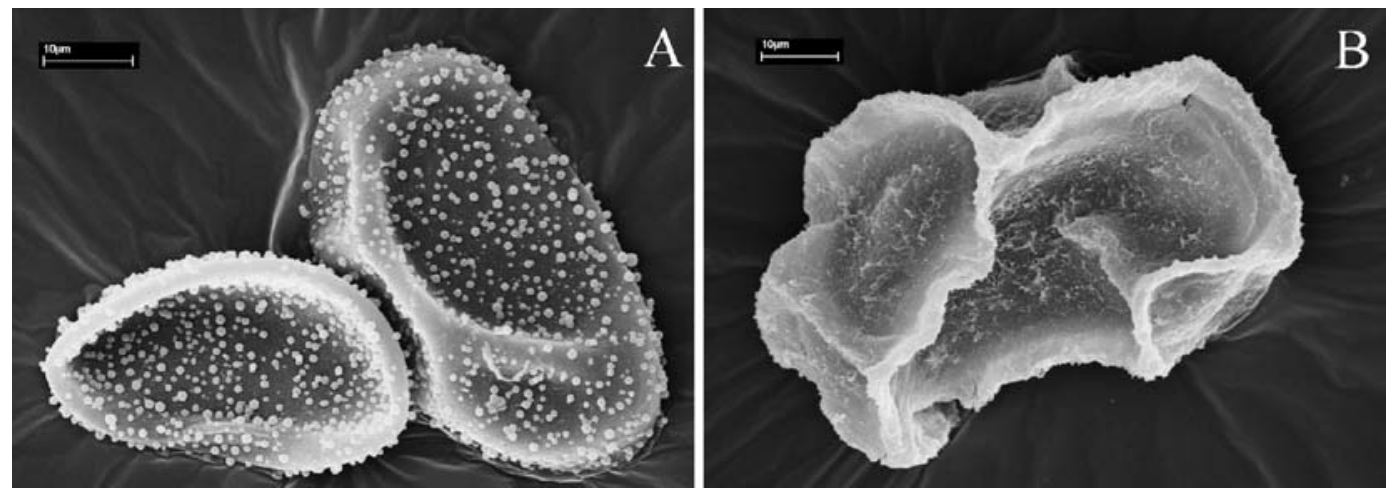

Fig. 2. SEM images of spores of two species of Elaphoglossum section Lepidoglossum subsection Muscosa. A. E. engelii, spore at left is collapsed (Kessler et al. 1120, GOET). B. E. cristatum (Kessler et al. 6875, GOET).

$0.4 \mathrm{~mm}$, ciliate, orange-brown; blades $6.5-12 \times$ $1.5-3 \mathrm{~cm}$, oblong-elliptic, basally and apically obtuse, moderately coriaceous, densely scaly; costal scales ovate-lanceolate, $1-4 \times 0.5$ $1.3 \mathrm{~mm}$, ciliate, orange-brown to blackish with paler margins; laminar scales peltate (more so abaxially), circular to ovate-lanceolate, 0.5 $2.5 \times 0.3-1 \mathrm{~mm}$, ciliate, orange- brown, sometimes with partly darkened cells; veins indistinct, unforked to once-forked, $0.5-1.5 \mathrm{~mm}$ apart; hydathodes absent; fertile fronds longer than sterile ones, blades lanceolate-elliptic, narrower and longer than sterile ones, with scales similar to those of sterile fronds; intersporangial scales present; spores ca. $70 \mu \mathrm{m}$ x 40 $\mu \mathrm{m}$, monolete, cristate, cristae $6-10 \mu \mathrm{m}$ in height, with scattered irregular deposits.

Distribution and ecology.-Bolivia, probably also in Peru and elsewhere in the tropical Andes (A. Vasco, pers. comm.). Shrubby humid vegetation above the closed timberline, where it grows in rock crevices among bushes and small trees of Baccharis, Oreopanax, and Polylepis pepei B. Simpson; 3700-3930 m.

Etymology.-The name refers to the cristate perispore.

Additional specimens examined. BOLIVIA. СоснавамвA: Prov. José Carrasco Torrico, $84 \mathrm{~km}$ antigua carretera Cochabamba-Villa Tunari, $17^{\circ} 15^{\prime} \mathrm{S}, 65^{\circ} 43^{\prime} \mathrm{W}$, 3750 m, 30 Jun 1996, Kessler et al. 6833 (GOET, LPB, NY, UC); Prov. Tiraque, El Ronco, $17^{\circ} 00^{\prime} 05^{\prime}$ 'S, 65 39'20"W, 3930 m, 10 May 2005, Zurita et al. 371 (BOLV, GOET).
Elaphoglossum cristatum differs from $E$. engelii mainly by its cristate spores with irregular deposits (Fig. 2b). All previous studies of the perispore structure of members of Elaphoglossum subsection Muscosa have revealed papillate structures, so that this has been proposed as a synapomorphy of the subsection (Moran et al., 2007) (Fig. 2a). Our finding shows that this is not the case and raises the question of how such a distinct spore type has evolved. Cristate spores are present in at least five independent lineages of Elaphoglossum, but are rare in the section Lepidoglossa (Moran et al., 2007). The phylogenetic and ontogentic bases for the development of different spore types in Elaphoglossum remain to be explored.

Morphologically, E. cristatum belongs in subsection Muscosa. It is distinguished from E. engelii mainly by more marginal cilia on the petiole scales $(50-80$ versus $10-30$ cilia per scale) and otherwise only in qualitative traits, namely the somewhat thicker blade texture, denser scale cover, and paler, more reddish rhizome scales. For this reason, positive identification may only be possible with fertile material. Indeed, a fourth collection from Bolivia (Jimenez 2342, GOET, LPB, NY) resembles E. cristatum morphologically but is not assigned by us to that species for lack of fertile material.

Elevationally, E. cristatum has been found at $3700-3930 \mathrm{~m}$ (3 collections), whereas $E$. engelii has been collected at $1800-3750 \mathrm{~m}$ 
(142 collections). Both species have been collected a few hundred meters from each other (M. Kessler, pers. obs.). One of the morphological traits of E. cristatum is its thicker, more densely blade scale cover relative to E. engelii. A study of E. palaceum (Hook. \& Grev.) Sledge has shown that a denser scale cover of the lamina protects the leaves from excess light and thereby from damage by photoinhibition (Watkins et al., 2006). It is conceivable that the dense scales of E. cristatum are similarly adaptations to the low temperatures and high insolation levels at high elevations.

\section{Acknowledgments}

We thank John T. Mickel, Robbin C. Moran, Jefferson Prado, and Alan R. Smith for valuable discussions and information on Elaphoglossum, Sabine Sommer for taking the SEM pictures, Marcus Lehnert for translating the Latin diagnosis, Dirk N. Karger for the drawing, and Lawrence Kelly, Robbin C. Moran, and Alejandra Vasco for valuable comments on the manuscript. This study was funded by the Deutsche Forschungsgemeinschaft and would have been impossible without the collaboration of Bolivian institutions (Dirección Nacional para la Conservación de la Biodiversidad; Herbario Nacional) and scientists, especially Stephan G. Beck and Iván Jimenez.

\section{Open Access}

This article is distributed under the terms of the Creative Commons Attribution Noncommercial License which permits any noncommercial use, distribution, and reproduction in any medium, provided the original author(s) and source are credited.

\section{Literature Cited}

Mickel, J. T. \& G. L. Atehortúa. 1980. Subdivision of the genus Elaphoglossum. American Fern Journal 70: 47-68.

Kramer, K. U. 1990. Lomariopsidaceae. In: K. Kubitzki (general ed.), K. U. Kramer \& P. S. Green (vol. eds.), The families and genera of vascular plants. Vol. 1. Pteridophytes and Gymnosperms. Springer Verlag, Berlin.

Moran, R. C., J. Garrison Hanks \& G. Rouhan. 2007. Spore morphology in relation to phylogeny in the fern genus Elaphoglossum (Dryopteridaceae). International Journal of Plant Sciences 168: 905-929.

Rouhan, G., J.-Y. Dubuisson, F. Rakotondrainibe, T. J. Motley, J. T. Mickel, J.-N. Labal \& R. C. Moran. 2004. Molecular phylogeny of the fern genus Elaphoglossum (Elaphoglossaceae) based on chloroplast non-coding DNA sequences: contributions of species from the Indian Ocean area. Molecular Phylogenetics and Evolution 33: 745-763.

Skog, J. E., J. T. Mickel, R. C. Moran, M. Volovsek \& E. A. Zimmer. 2004. Molecular studies of representative species in the fern genus Elaphoglossum (Dryopteridaceae) based on cpDNA seuqnces rbcL, trnL-F, and rps4-TRNS. International Journal of Plant Sciences 165: 1063-1075.

Watkins, Jr. J. E., A. Y. Kawahara, S. A. Leicht, J. R. Auld, A. J. Bicksler \& K. Kaiser. 2006. Fern laminar scales protect against photoinhibition from excess light. American Fern Journal 96: 83-92. 